\title{
Morphological Characteristics and Nutritional Values of Wild Types of Sago Mushrooms (Volvariella sp.) That Growth Naturally in Manokwari, West Papua
}

\author{
Elda Christian Paisey, Barahima Abbas* \\ Faculty of Agriculture, University of Papua (UNIPA), Manokwari, Indonesia \\ Email: "barahimabas@gmail.com
}

Received 2 November 2015; accepted 12 December 2015; published 15 December 2015

Copyright (C) 2015 by authors and Scientific Research Publishing Inc.

This work is licensed under the Creative Commons Attribution International License (CC BY). http://creativecommons.org/licenses/by/4.0/

\section{(c) (;) Open Access}

\begin{abstract}
Sago mushrooms (SMs) are an edible fungus that is favorite food for community in Papua and West Papua, Indonesia in particular. This work aims to determine the morphological characteristics and nutritional value of SMs growing naturally in Manokwari. Morphological characteristic of SMs that grows wild in Manokwari has an average of pileus diameter $9.53 \mathrm{~cm}$, pileus weight 21.53 grams, and pileus color. The pileus color is divided into three colors: outer circle color is RHS163D, middle circle color is RHS199B, and inner circle color is RHS199A. Average of stipe diameter, length, and weight is $1.00 \mathrm{~cm}, 10.43 \mathrm{~cm}$, and 9.15 gram respectively. Stipe is a yellowish white color (RHS155B). SMs nutrient content that grows naturally in Manokwari is potassium 1394.02 milli-grams and calcium 13.37 milligrams per 1000 grams fresh weight. The others nutrient contents of SMs that are measured are fat 1.01 grams, protein 1.30 grams, carbohydrates 0.18 grams, phosphorus 0.34 milligrams, and energy 15.01 kilocalories per 100 grams of fresh weight.
\end{abstract}

\section{Keywords}

Sago Mushroom, Morphology, Nutritional Value, Wild Types, Manokwari

\section{Introduction}

Indonesia is rich in the diversity of edible mushrooms resources that have not been explored to be utilized to the maximum. Papua has a lot of varieties of edible mushrooms, one of which is the SMs. Sago mushrooms (SM) in

"Corresponding author.

How to cite this paper: Paisey, E.C. and Abbas, B. (2015) Morphological Characteristics and Nutritional Values of Wild Types of Sago Mushrooms (Volvariella sp.) That Growth Naturally in Manokwari, West Papua. Natural Science, 7, 599-604. http://dx.doi.org/10.4236/ns.2015.713059 
Papua has not been much reported, in the aspect of its characteristics, nutrient contents, as well as domestication. Fungus that grows naturally in extraction waste of sago palm is called SM. SMs resembles Volvariella volvacea, but there are many differences with $V$. volvacea. SM also has an organ called volvas as well as $V$. volvacea which is the main fungi characters of the genus Volvariella [1].

SMs (Volvariella sp.) is a fungus that grows sporadically in the sago waste and sago stems that are decaying. SMs existence that grows naturally erratic and rare. Community in Papua is delighted to find SM in sago forests. People enjoy eating SMs because it tastes good and delicious. Edibel mushrooms are rich in essential amino acids such as leucine, isoleucine, valine, tryptophan, lysine, theonin, phenilalanin, methinin and histidine [2] and [3]. Edibel mushrooms are also rich in unsaturated fatty acids and hypothetical. It can decrease cholesterol level in the blood of the human because it has contained low density lipoprotein in the blood [4]. In addition, the mushroom also has anti-virus and bacteria, thus increasing the body's resistance to disease.

Based on morphological appearance of SM, it looks like more related with $V$. volvacea than other Volvariella species. Morphological description of $V$. volvacea is reported that the pileus diameter is 5 to $10 \mathrm{~cm}$, that pileus color is gray, that stipe length exceeds $2 \mathrm{~cm}$ and that spore size is 7 to $10.5 \mu \mathrm{m}$ and widely distributed [1]. [5] revealed that measurements of the nutritional value, morphology and microscopic of SM origin Serui were different from V. volvacea. Beside, SM was found in Serui region also. It is growing wild in many other regions in the Papua and West Papua. Types of SM that grows naturally in various regions in Papua are not known certainty, so it needs to observe and characterize the SM characteristics.

\section{Materials and Methods}

This research was conducted in Manokwari, West Papua province, Indonesia. Samples were taken by way of observation of overall sago waste of the people in west Papua. The presence of SM that grows in the sago waste was collected for measuring the characteristics and nutrient values. Identification of SM that was found is followed by [6] [7] methods. Morphological characteristics of mature SM are based on the size and character of stipe, pileus, lamellae, spores, and hyphae. Nutrition contents that were measured are protein, fat, carbohydrates, energy and minerals (calcium, phosphorus and potassium). stipe and pileus organs measured by using a ruler and calipers. Lamellae color is determined by using color chart, the sizes and shapes of the spores are determined using a microscope, so did the size of the hyphae. Before observed under a microscope, spores and hyphae stained with a solution of Lactophenol Blue $(\mathrm{CH} 3 \mathrm{CH}(\mathrm{OH}) \mathrm{COOH})$ then it is observed using a microscope magnification of 400 times and 1000 times. Spores were observed it is taken from SMs maturity and growth normally, being hyphae were observed were taken from pure cultures that were previously grown on Knudson $(\mathrm{KnC})$ medium which enriched with maturity of coconut water. Nutritional contents of SM were analyzed in the Laboratory of Food Technology, Bogor Agricultural University. Determination of protein content is done by using the Micro Kjeldahl method, the fat content was determined using Soxhlet method, carbohydrate content was determined using the method by difference, the levels of calcium (Ca) and potassium (K) was determined using AAS method, and phosphorous (P) content was determined using Spectrophotometer.

\section{Results and Discussion}

\subsection{Exploration of Sago Mushroom (SM)}

SMs were observed in Manokwari it was found consists of three growth stages that is maturity stage, elongation stage, and egg stage (Figure 1). The SM were found it growth on sago waste that are decaying in the field. Growth stages of mushroom were divided into six stages that is pinhead (primordia), tinny button (small button), buttons (buttons), egg (oval), elongation (stipe formation), and maturity [8].

Sago mushrooms grow naturally in the sago waste of society, if by chance at the sago waste disposal sites there SM spores or SM hyphae that contained in the soil. Sago waste are discarded by people or extractor still has $10.71 \%$ carbohydrate content, $2.06 \%$ crude fiber, $0.64 \% \mathrm{~N}, 0.20 \% \mathrm{P}, 1.44 \% \mathrm{~K}$, and $6.98 \mathrm{pH}$, water content $71.66 \%$, [9] which is suitable for growing SM. This condition is suitable for SM growth while V. volvacea can growth and produce high basidiocarps on the medium of rice straw [10].

\subsection{Visual Characterization of SMs}

Based on SMs were found in the Manokwari district it show that stipe length range from 7 to $14 \mathrm{~cm}$, stipe 


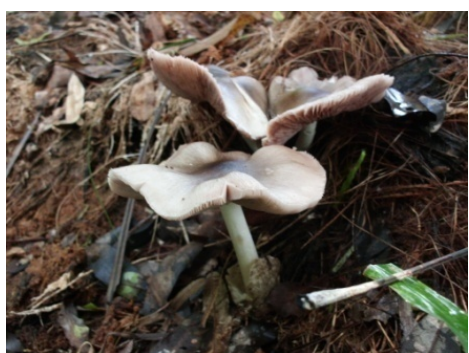

(a)

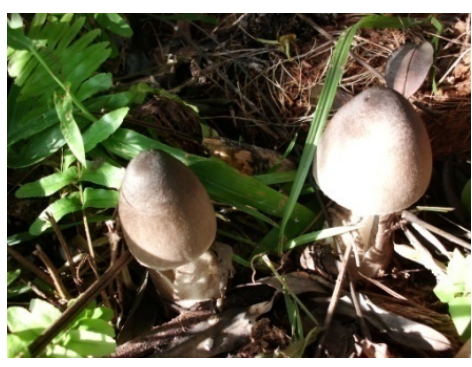

(b)

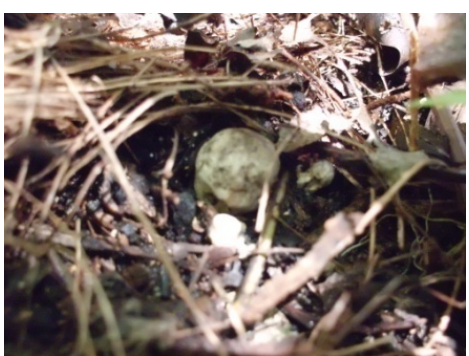

(c)

Figure 1. Performance of sago mushroom was found growth naturally in Manokwari. Maturitystage (a), elongation stage (b), and egg stage (c).

diameter among 0.82 to $1.20 \mathrm{~cm}$ (Table 1) and the stipe color is yellowish white (RHS155B) (Table 2). The presence of volvas organ at the base of the stipe is indicated that is a genus of Volvariella. The main characteristic of Volvariella has an organ that is like thin membrane surrounds the base of the stipe and a mushroom fruit body wrap while still young, called volvas [7] [11] [12]. Edible mushrooms that have similarities with SMs are $V$. volvacea and $V$. gloiocephala. [8] reported that the stipe length of $V$. volvariella about 5 to $8 \mathrm{~cm}$, the stipe diameter 0.5 to $1.5 \mathrm{~cm}$ and the lamellae is white.

Besides stipe organ of the SM any other organ is pileus. Pileus is a mushroom-shaped umbrella hood when they reach mature stage. Pileus sizes of the SMs were found in Manokwariit has diameter range from 8.20 to $11.81 \mathrm{~cm}$ with a weight of pileus range from 15.53 to 35.90 grams (Table 1 ) and has a different color on the outer edge of the circle, and the circle in the middle (Figure 2). Pileus color in the outside circle is light yellowish brown (RHS163D), in middle circle is moderate light yellowish brown (RHS199B) and the inner circle is moderate brown (RHS199A). The color performance of volvas, stipe, pileus, and lamellae organs is presented (Table 2). If pileus SM compared with $V$. volvacea, pileus of SMs have a size larger then straw mushroom pileus because the straw mushroom just has around 5 to10 cm in the diameters [1]. Pileus sizes and pileus colors of SMs that were found in Manokwari are resembled with SMs that were found in Serui [5]. Lamellae organ of SMs is look like the gills of fish and there are contained many spores. The color of SMs lamellae is brownish orange (RHS164A) when just cap is open and moderate brown (RHS165A) when will decay. SMs morphological characteristics differ from V. volvacea and V. gloiocephala [5] nevertheless color of SMs Lamellae has similarities with $V$. gloiocephala is RHS164A.

\subsection{Microscopic Characterization of SMs}

SMs hyphae that was found in Manokwari region were shown the hyphae is white and diameter hyphae is range 8.0 to $11.7 \mu \mathrm{m}$ as well as the hyphae type is partition. The size of the fungal hyphae SMs was found in Manokwari no different from those found in Yapen Warpen ranging from $8 \mu \mathrm{m}$ to $11 \mu \mathrm{m}$ [5]. SMs hyphae are greater when compared with straw mushroom hyphae. Straw mushroom hyphae were measuring $6 \mu \mathrm{m}$ [8]. The performance of SMs hyphae and spores that is grows wild in Manokwari is presented in Figure 3. SMs spores are shiny yellow color. The shape of SMs spore is round to oblong resembling SMs spores were found growing wild in Yapen Waropen [5].

\subsection{Nutrient Contents of SMs}

The composition of the nutrient content of SMs were found growth naturally in Manokwari slightly different from the composition of the nutrient content of SMs were found growth naturally in Yapen Waropen (Table 3). Nutrient contents of SMs from Manokwari are protein 1.30 grams per 100 grams, carbohydrates 0.18 gram per 100 grams, fats 1.01 grams per 100 grams, phosphorus (P) 0.34 mg per 100 grams, Potassium (K) 1394.02 mg per 1000 grams, calcium (Ca) 13.37 mg per 1000 grams (Table 3). Protein, carbohydrates, calcium, and phosphorus contents of SMs from Manokwari lower than SMs from Yapen Pro Waropen. Otherwise the calcium content of SMs from Manokwari higher than SMs from Yapen Waropen. Nutritional differences may be caused by the state of the place of growth. Volvariella species has very high water content, high carbohydrates and protein content, and relatively rich of potassium [13]. 


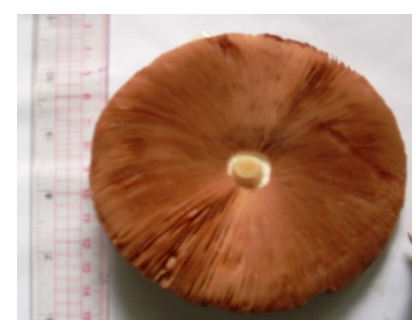

(a)

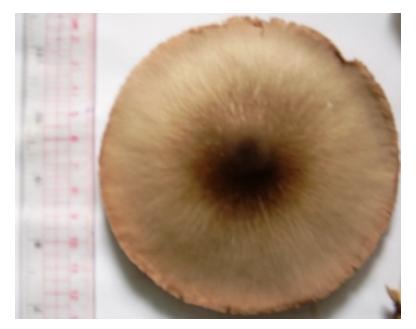

(b)

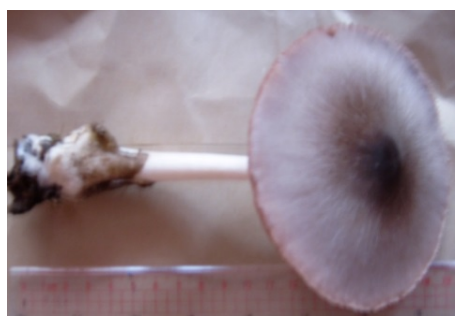

(c)

Figure 2. Morphological performance of SMs that were observed in Manokwari region. Lamellae (a), pileus (b), maturity stage (c).

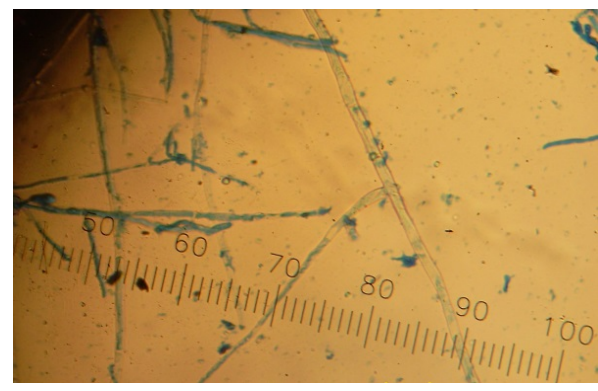

(a)

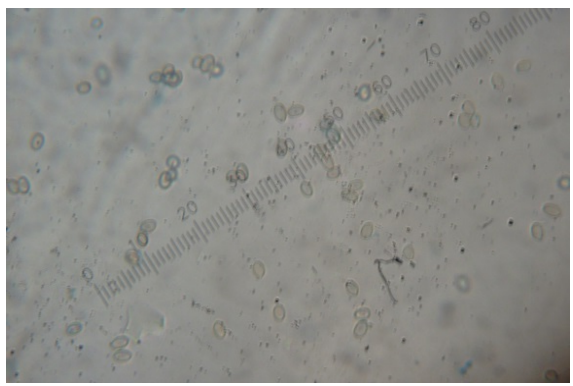

(b)

Figure 3. Microscopic performance of SMs hyphae and spores grow wild in Manokwari. Hyphae at 1000× magnification (a) and spores at $400 \times$ magnification (b).

Table 1. Morphological Characteristics of SMs that was found in Manokwari region.

\begin{tabular}{cccccc}
\hline \multirow{2}{*}{ Sample } & \multicolumn{2}{c}{ Pileus } & \multicolumn{3}{c}{ Stipe } \\
\cline { 2 - 6 } & Diameter $(\mathrm{cm})$ & Fresh Weight (gram) & Diameter $(\mathrm{cm})$ & Length $(\mathrm{cm})$ & Fresh Weight (gram) \\
\hline 1 & 8.16 & 16.07 & 0.82 & 7.00 & 5.95 \\
2 & 8.12 & 18.01 & 1.02 & 10.50 & 8.20 \\
3 & 8.48 & 18.06 & 0.86 & 10.50 & 7.00 \\
4 & 9.81 & 17.54 & 1.01 & 10.50 & 9.59 \\
5 & 9.39 & 15.53 & 1.02 & 10.00 & 7.75 \\
6 & 11.81 & 30.35 & 1.20 & 14.50 & 14.80 \\
7 & 10.97 & 35.90 & 1.09 & 10.00 & 10.75 \\
\hline Average & 9.53 & 21.64 & 1.00 & 10.43 & 9.15 \\
\hline
\end{tabular}

Table 2. Color performance of SMs organs that were observed in Manokwari regions.

\begin{tabular}{|c|c|c|c|c|c|c|}
\hline \multirow{2}{*}{ Sample } & \multicolumn{3}{|c|}{ Pileus Color } & \multirow{2}{*}{ Stipe Color } & \multirow{2}{*}{ Volvas Color } & \multirow{2}{*}{ Lamellae Color } \\
\hline & OC & MC & IC & & & \\
\hline 1 & RHS163D & RHS199B & RHS199A & RHS155B & RHS197A & RHS165A \\
\hline 2 & RHS163D & RHS199B & RHS199A & RHS155B & RHS197A & RHS165A \\
\hline 3 & RHS163D & RHS199B & RHS199A & RHS155B & RHS197A & RHS165A \\
\hline 4 & RHS163D & RHS199B & RHS199A & RHS155B & RHS197A & RHS165A \\
\hline 5 & RHS163D & RHS199B & RHS199A & RHS155B & RHS197A & RHS165A \\
\hline 6 & RHS163D & RHS199B & RHS199A & RHS155B & RHS197A & RHS165A \\
\hline 7 & RHS163D & RHS199B & RHS199A & RHS155B & RHS197A & RHS165A \\
\hline
\end{tabular}

Notes: OC = Outer Circle, MC = Middle Circle, IC $=$ Inner Circle, RHS163D $=$ light yellow, RHS199B $=$ Light Olive Brown, RHS199A = Moderate Olive Brown, RHS155B = Yellowish White, RHS197A = Light Olive Gray, RHS165A = Moderate Brown. 
Table 3. Nutrient content of the SMs that grow naturally in Manokwari.

\begin{tabular}{|c|c|c|}
\hline Nutrien/Fresh Weight & SMs Wild Types in Manokwari & SMs Wild Types in Yapen Waropen [5] \\
\hline Protein & 1.30 gram/100 gram & 4.00 gram/100 gram \\
\hline Carbohydrates & 0.18 gram/100 gram & 2.99 gram/100 gram \\
\hline Fat & 1.01 gram/100 gram & 0.19 gram/100 gram \\
\hline Calcium & 13.37 mg/1000 gram & 11.53 milligram/1000 gram \\
\hline Potassium & $1394.02 \mathrm{mg} / 1000$ gram & 165.05 milligram/1000 gram \\
\hline Phosphor & $0.34 \mathrm{mg} / 100$ gram & 310 milligram/100 gram \\
\hline Ash & 0.33 gram/100 gram & 300 milligram/100 gram \\
\hline Water & 97.18 gram/100 gram & 92.52 gram/100 gram \\
\hline Energy & 15.01 Kilocalories & Not Recorded \\
\hline
\end{tabular}

Notes: Analysis of the nutritional content of SMs from Manokwari and SMs from Serui were conducted at the Laboratory of Food Analysis Services IPB. SMs from Manokwari were analyzed in 2015 and SMs from Yapen Waropen were analyzed in 2009.

\section{Conclusion}

Morphological characteristic of SM that grows wild in Manokwari has an average of pileus diameter $9.53 \mathrm{~cm}$, pileus weight 21.53 grams, and pileus color. The pileus color is divided into three colors: outer circle color is RHS163D, middle circle color is RHS199B, and inner circle color is RHS199A. Average of stipe diameter, length, and weight is $1.00 \mathrm{~cm}, 10.43 \mathrm{~cm}$, and 9.15 gram respectively. Stipe is a yellowish white color (RHS155B). SMs nutrient content that grows naturally in Manokwari is potassium 1394.02 milligrams and calcium 13.37 milligrams per 1000 grams fresh weight. The others nutrient contents of SMs that are measured are fat 1.01 grams, protein 1.30 grams, carbohydrates 0.18 grams, phosphorus 0.34 milligrams, and energy 15.01 kilocalories per 100 grams of fresh weight.

\section{Acknowledgements}

Thanks go to the project managers of Competitive Research Grant (Hibah Bersaing) number 150/SP2H/PL/ DIT.LITABMAS/11/2015 Fiscal Year 2015 for providing and supporting the research financials. Grateful is also extended to all those who are involved in this work.

\section{References}

[1] Kuo, M. (2008) The Genus Volvariella. Retrieved from the Mushroom Expert. http://www.mushroomexpert.com/volvariella.html

[2] Jordan, M. (1993) Edible Mushroom and Other Fungi. Blanford, London.

[3] Widiyastuti, B. (2005) Cultivation of Compost Mushroom: Straw Mushroom and Champignon Mushroom (in Indonesian Language). Penebar Swadaya, Jakarta.

[4] Chang, S.T. (1999) Global Impact of Edible and Medical Mushroom on Human Welfare in the 21st Century. International Journal of Medical Mushroom, 1, 1-7.

[5] Abbas, B., Listyorini, F.H. and Martanto, E.A. (2011) Sago Mushrooms Characteristics (Volvariella sp.) which Endemism in Papua (in Indonesian Language). Jurnal Natur Indonesia, 2, 168-173.

[6] Alxopoulos, C.J. and Mims, C.W. (1979) Introductory Mycology. 3rd Edition, John Willey \& Sons, New York.

[7] Landecker, E.M. (1990) Fundamental of the Fungi. 3rd Edition, Prentice-Hall, Inc., A Division of Simon \& Schuster, Englewood Cliffs.

[8] Chang, S.T. (1964) A Morphological Study of Volvariella volvacea. The Chung Chi Journal, 3, 91-103.

[9] Uruilal, C., Kalay, A.M., Kaya, E. and Siregar, A. (2012) Utilizationof Sago Waste, Hull Rice, Bran Rice as Medium for Multiplication of Biological Agent of Trichoderma harzianum Rifai (in Indonesian Language). Agrologia, 1, 21-30.

[10] Thiribhuvanamala, G., Krishnamoorthy, S., Manoranjitham, K., Praksasm, V. and Krishnan, S. (2012) Improved Techniques to Enhance the Yield of Paddy Straw Mushroom (Volvariella volvacea) for Commercial Cultivation. African 
Journal of Biotechnology, 64, 12740-12748.

[11] Li, G.S.F. (1982) Morphology of Volvariella volvacea. In: Chang, S.-T. and Quimio, T.H., Eds., Tropical Mushrooms: Biological Nature and Cultivation Methods, 117-160.

[12] Moncalvo, J.M., Vilgalys, R., Redhead, A., Johnson, J.M., James, T.Y., Aime, M.C., Hofstetter, V., Verduin, S.J.W., Larson, E., Baroni, T.J., Thorn, R.G., Jacobsson, S., Clemencon, H. and Miller, O.K. (2002) One Hundred and Seventeen Clades of Euagarics. Molecular Phylogenetics and Evolution, 23, 357-400. http://dx.doi.org/10.1016/S1055-7903(02)00027-1

[13] Sahoré, A.D., Nemlin, J.G. and Tetchi, A.F. (2012) Study of Physicochemical Properties of Some Traditional Vegetables in Ivory Coast: Seeds of Beilschmiedia mannii (Lauraceae), Seeds of Irvingia gabonensis (Irvingiaceae) and Volvariella volvaceae. Food and Nutrition Sciences, 3, 14-17. http://dx.doi.org/10.4236/fns.2012.31003 